\title{
Campylobacter inoculation and quantification from broiler cecal samples to compare two plate counting methodologies
}

\section{Inoculação e quantificação de Campylobacter a partir de conteúdo cecal de frangos de corte comparando duas metodologias de contagem}

\author{
Anderlise Borsoi ${ }^{*}$; Camila Cristina Gonsalves²; Edson Ricardo Marcondes Pires ${ }^{2}$; \\ Laura Beatriz Rodrigues ${ }^{3}$; Luciana Ruschel dos Santos ${ }^{3}$; \\ Vladimir Pinheiro do Nascimento ${ }^{4}$
}

\begin{abstract}
Campylobacteriosis is a zoonosis, a disease transmitted to humans from animals or animal products. The primarily source of Campylobacter infection in human is believed to be the handling and/or consumption of contaminated meat, especially poultry meat. Although in humans such infections are generally self-limiting, complications can arise and may include bacteraemia, Guillain-Barré syndrome, reactive arthritis and abortion. In this study, 32 birds were divided in 2 groups: a control (C) group and an inoculated (I) group, with 16 birds each. The I group was inoculated orally with $10^{8} \mathrm{CFU} / \mathrm{mL}$ of Campylobacter jejuni ATCC 33291, whereas the C group was inoculated with a saline solution. Four chicks per group were euthanized by cervical dislocation at $0,7,14$ and 21 days post-inoculation (pi). Cecum samples were collected for microbiological analyses. The samples were processed by two plate count methodologies, one developed by the USDA (United States Department of Agriculture) in 2011 (B method) and the other a serial dilution direct count method (A method). All birds from the $\mathrm{C}$ group remained negative until day 21 . For the I group, the B method was found to be statistically superior to the A method for counting the recovered cells from the cecal contents at 7,14 and 21 days pi. The microbiological direct plating counting method is a cost effective and rapid method to determine the level of contamination in broilers to help risk assessment programs at the industry level.
\end{abstract}

Key words: Campylobacter, direct plate count, broiler, cecal content

\section{Resumo}

Campilobacteriose é uma zoonose, uma doença transmitida para humanos por animais ou produtos de origem animal. As fontes primárias de infecções por Campylobacter em humanos se acredita ser o manuseamento e / ou o consumo de carne contaminada, carne de frangos especialmente. Embora em humanos tais infecções são geralmente auto-limitantes, as complicações podem surgir e podem incluir bacteremia, síndrome de Guillain-Barré, artrite reativa e aborto. Para o presente estudo, 32 aves foram divididos em 2 grupos identificados como grupos controle (C) com 16 aves e grupo inoculado (I) com 16 aves. O grupo I foi inoculado por via oral com $10^{8} \mathrm{UFC} / \mathrm{mL}$ de Campylobacter jejuni ATCC 33291,

\footnotetext{
${ }^{1}$ Prof., Universidade Tuiuti do Paraná, UTP, Curitiba, PR, Brasil. E-mail: anderliseb@yahoo.com.br

${ }^{2}$ Discentes de Graduação do Curso de Medicina Veterinária, UTP, Curitiba, PR, Brasil. E-mail: camila_c_gonsalves@hotmail. com; esdsonpiresmv@gmail.com

${ }^{3}$ Profs., Universidade de Passo Fundo, UPF, Passo Fundo, RS, Brasil. E-mail: laurab@upf.br; luruschel@upf.br

${ }^{4}$ Prof., Universidade Federal do Rio Grande do Sul, UFRGS, Porto Alegre, RS, Brasil. E-mail: vladimir@orion.ufrgs.br

* Author for correspondence
} 
enquanto o grupo $\mathrm{C}$ foi inoculado com solução salina. Quatro aves por grupo foram eutanaziados por deslocamento cervical nos dias 0, 7, 14 e 21 após a inoculação (pi) e as amostras de conteudo cecal foram coletadas para análises microbiológicas. As amostras foram processadas por duas metodologias de contagem em placa, uma desenvolvido pela USDA (método B) e outra, por diluição seriada com plaqueamento direto (método A). Todas as aves do grupo $\mathrm{C}$ permaneceram negativas até ao dia 21 , e para o grupo I, as células recuperadas a partir de conteúdo cecal foram estatisticamente superior com o método B, quando comparados ao método A nos 7, 14 e 21 dias pi. A contagem microbiologica direta em placas é um método masi barato e rápido para determinar o nível de contaminação de frangos, servindo de auxilio nos programas de avaliação de risco a nível da indústria.

Palavras-chave: Campylobacter, contagem direta em placa, frangos, conteúdo cecal

Campylobacter (C) bacteria are a major cause of foodborne diarrheal illness in humans and are the most common bacteria that cause gastroenteritis worldwide. In developed and developing countries, they cause more cases of diarrhea than foodborne Salmonella. (WHO, 2011).

Campylobacter spp. have been the focus of growing attention for the past 30 years because of the increasing frequency with which they have been isolated from man, animals, food and water. Although several Campylobacter spp. have been shown to cause diarrhea, $C$. jejuni is by far the most frequent species isolated from man. C. jejuni is a frequent cause of morbidity in both industrialized and developing countries and represents a considerable drain on economic and public health resources (BUTZLER, 2004).

Campylobacteriosis is a zoonosis, a disease transmitted to humans from animals or animal products, through carcasses or meat contaminated by Campylobacter during slaughtering (WHO, 2011). Positive flocks entering the slaughter line can contaminate uninfected carcasses and the abattoir environment. Cross-contamination, therefore, is believed to represent a significant problem for the poultry industry (CORRY; ATABAY, 2001). Over $80 \%$ of cases are caused by $C$. jejuni, and approximately $10 \%$ of cases are caused by $C$. coli. In humans, C. jejuni/coli infection is associated with acute enteritis and abdominal pain lasting for 7 days or more. Although such infections are generally self-limiting, complications can arise and may include bacteraemia, Guillain-Barré syndrome, reactive arthritis and abortion. The primarily source of C. jejuni/coli infections in human is believed to be the handling and/or consumption of contaminated meat, especially poultry meat (OIE, 2008).

For carrying out a quantitative risk assessment of human campylobacteriosis related to chicken and chicken products, especially focusing on the exposure assessment, quantitative data on the Campylobacter spp. present on poultry are necessary but still insufficient. Currently, attempts to quantify Campylobacter in the poultry processing chain are based on methodologies with enrichment or direct counting. The direct plating procedure is a rapid and effective alternative method for the enumeration of Campylobacter when compared to enrichment procedures. The aim of this study was to compare the FISIS (USDA, 2011) direct counting method published in 2011 with a serial dilution and direct plating method to quantify Campylobacter from the cecal content of inoculated broiler chickens.

In the present work, 32 newly hatched commercial Cobb chicks were obtained from a Brazilian poultry company. All of the chicks were Salmonella and Campylobacter-free and were housed in floor-pens. Water and feed that were free from antibiotics and animal protein were offered $a d$ libitum, and the environmental temperature was set to provide physiological comfort. The 32 birds were divided in 2 groups, identified as control (C) and inoculated (I) groups. The I group was inoculated orally with $10^{8} \mathrm{CFU} / \mathrm{mL}$ of Campylobacter jejuni ATCC 33291, whereas the C group was inoculated with a saline solution. Four chicks per group were 
euthanized by cervical dislocation at $0,7,14$ and 21 days pi. Cecum samples were collected for microbiological evaluation.

One gram of cecal content from each bird was homogenized in $9 \mathrm{~mL}$ of $1 \%$ buffered peptone water (BPW, Oxoid, United Kingdom) and diluted 10-fold up to $10^{-5}$.

For the direct plating method (A method), 100 $\mu \mathrm{L}$ from previous dilutions $\left(10^{0}\right.$ to $\left.10^{-5}\right)$ were spread radially, in duplicate, with a Drigalski holder onto an mCCDA (Oxoid, United Kingdom) agar plate with antimicrobial supplements (SR0155E, Oxoid, United Kingdom) and then incubated under microaerophilic conditions at $42^{\circ} \mathrm{C}$ for $48 \mathrm{~h}$. The bacterial counts were averaged from countable (30 to $300 \mathrm{CFU}$ ) plates and multiplied by the dilution factor. For the FISIS method (B method), according to MLG Chapter 41.01 (USDA, 2011), $250 \mu \mathrm{L}$ of the initial dilution $\left(10^{\circ}\right)$ were dispensed onto four agar plates and $100 \mu \mathrm{L}$ onto two other plates. The six plates were incubated as described above. The bacterial count (plates with 15 to 300 CFU) was performed according the methodology instructions. Campylobacter jejuni ATCC 33291 controls were incubated and analyzed as were the samples. At the same time, $1 \mathrm{~mL}$ from the $10^{\circ}$ dilution of each sample was incubated in 9 $\mathrm{mL}$ of Bolton Broth (Oxoid, United Kingdom) with antimicrobial supplements (SR0183E, Oxoid, United Kingdom) for $48 \mathrm{~h}$ at $42^{\circ} \mathrm{C}$ in microaerophilic conditions and then streaked onto an mCCDA agar plate with antimicrobial supplements and then incubated at the temperature described above. Four colonies per sample were confirmed by motility, biochemical tests (oxidase and catalase) and a latex agglutination test (Dryspot Test Kit, DR0150, Oxoid, United Kingdom) according the FISIS methodology.

Final data were submitted to variance analysis using BioStat (2009) software (AnalystSoft. Inc. USA), and the means were compared using Tukey's $t$-test at a $5 \%$ significance level $(p<0.05)$.
The results of the microbiological evaluations are presented in Table 1. In the C group, all of the birds remained Campylobacter jejuni negative until day 21 pi, even after the enrichment protocol. Regardless of Campylobacter isolation from the intestinal tract of chickens, the enrichment of samples has been commonly used in inoculation experiments or in naturally occurring colonization studies (PEARSON et al., 1993; SHREEVE et al., 2000; DHILLON et al., 2006). However, the use of direct plating of fecal samples may be a faster method for the isolation of Campylobacter from fecal samples, and it has been shown that direct plating can be used successfully for the isolation of Campylobacter from broiler samples (OYARZABAL et al., 2005).

Table 1. Results from the two methods of counting Campylobacter jejuni from cecal samples from inoculated broiler chicks.

\begin{tabular}{cccc}
\hline $\begin{array}{c}\text { Pi } \\
\text { Days }\end{array}$ & $\begin{array}{c}\text { A method CFU/ } \\
\mathrm{mL}(\log 10)\end{array}$ & $\begin{array}{c}\text { B method CFU/ } \\
\mathrm{mL}(\log 10)\end{array}$ & $\mathrm{p}$ \\
\hline 0 & 0 & 0 & 0 \\
7 & 2.32 & 3.18 & 0.193 \\
14 & 1.18 & 2.79 & 0.0002 \\
21 & 1.18 & 2.18 & 0.0011 \\
\hline
\end{tabular}

Pi: Post-inoculation; A method: FISIS; B method: direct plating; CFU: unity forming colony; p: 5\% significance level

Source: Elaboration of the authors.

To perform this work, we selected mCCDA media instead of Campy-Cefex, as was originally used for the FISIS method, because it is the media of choice for isolation of Campylobacter from fecal and cecal samples from broiler chickens (POTTURI-VENKATA et al., 2007). The two methodologies tested were not developed specifically for use with fecal samples; however, both methods were capable of recovering Campylobacter jejuni ATCC 33291 bacteria from broiler cecal samples. The B method was capable of recovering a higher number of Campylobacter cells from cecal content $\left(3.18,2.79\right.$ and $2.18 \log _{10}$ 
$\mathrm{CFU} / \mathrm{g})$ than the A method $(2.32,1.18$ and 1.18 $\log _{10} \mathrm{CFU} / \mathrm{g}$ at day 7,14 , and $21 \mathrm{pi}$, respectively). The difference between these methods was the amount of bacterial suspension plated and the method used to calculate the final number. It is likely that the B method leads to a higher recovery rate because it was designed to analyze poultry rinsates and environmental sponge samples that contain few cells. The number of Campylobacter bacteria on broiler carcass was estimated by researchers (HABIB et al., 2012) in Belgium, and more than $50 \%$ of 389 carcasses were contaminated with $<10 \mathrm{CFU} / \mathrm{g}$. In the $\mathrm{EU}$, the cost of campylobacteriosis to public health systems and to lost productivity is estimated to be approximately 2.4 billion Euros each year. Experts from the EFSA (European Food Safety Authority) say that measures before slaughter could reduce the risk by up to $50 \%$, although this figure is expected to vary considerably between member states. Such measures primarily focus on preventing the bacteria from entering the housing in which the chickens are kept and on reducing the number of Campylobacter in the intestines of chickens sent to slaughter (EFSA, 2011).

It is unclear whether enriching samples from broilers is a useful culturing technique for isolating Campylobacter. Certain studies have indicated that enrichment does not enhance the recovery of Campylobacter from poultry fecal, cecal, crop, and broiler carcass samples (MUSGROVE et al., 2001). Others have determined that when enrichment broth is used, the isolation rate of Campylobacter from human feces can be increased (BOLTON; ROBERTSON, 1982). Musgrove and co-workers (2001) found a decrease of $36.7 \%$ in the detection of Campylobacter spp. in cecal samples with enrichment compared to the direct plating procedure. These results were explained by the fact that more species are present in the ceca. Campylobacter spp. has a slower growth rate than many other bacterial species and competes poorly outside of its intestinal niche.
A general observation, and a distinct characteristic of Campylobacter jejuni colonization in poultry, is that this organism is not detected in chicks less than 2 to 3 weeks of age under commercial broiler production conditions (SHREEVE et al., 2000). In the present study, we investigated a control group with saline inculcation, and the birds remained negative until day 21. It was expected that some birds would be positive at 21 days because of Campylobacter colonization and excretion in broilers as described previously. This result may indicate that a field environment is necessary for broilers to shed this bacteria.

Despite insufficient knowledge about Campylobacter in broilers and the risk of this meat causing Campylobacter outbreaks, it is necessary to understand factors that govern Campylobacter contamination in carcasses, and there is a need for intensive microbiological baseline studies. Quantitative and qualitative microbiological data from baseline studies within the poultry industry are important for safety management programs. Thus, cost-effective, fast and simple methodologies are necessary to improve the surveillance quality in all steps of broiler production.

This study shows that it is possible to use a welldescribed methodology to count Campylobacter from broiler cecal samples and that perhaps could be extend to other field samples.

\section{References}

BioStat, 2009 software (AnalystSoft. Inc. USA). 2009. Available at: <http://biostat-professional. joydownload. com.br/>. Accessed at: 07 jan. 2011.

BOLTON, F. J.; ROBERTSON, L. A selective medium for isolating Campylobacter jejuni/coli. Journal of Clinical Pathology, London, v. 35, n. 4, p. 462-467, 1982.

BUTZLER, J. P. Campylobacter, from obscurity to celebrity. Clinical Microbiology and Infections, Switzerland, v. 10, n. 10, p. 868-876, 2004.

CORRY, J. E. L.; ATABAY, H. I. Poultry as a source of Campylobacter and related organisms. Journal of Applied Microbiology, Oxford, v. 90, n. 1, p. 96-114, 2001. 
DHILLON, A. S.; SHIVAPRASAD, H. L.; SCHABERG, D.; WIER, F.; WEBER, S.; BANDLI, D. Campylobacter jejuni infection in broiler chickens. Avian Disease, Florida, v. 50, n. 1, p. 55-58, 2006.

EUROPEAN FOOD SAFETY AUTHORITY - EFSA. EFSA issues advice on reduction of Campylobacter in chickens. [S.1.]: Parma, 2011. Available at: <http:// www.efsa.europa.eu/en/press/news/biohaz110407.htm>. Accessed at: 02 apr. 2011.

HABIB, I.; BERKVENS, D.; De ZUTTER, L.; DIERICK, K.; VAN HUFFELE, X.; SPEYBROECKF, N.; GEERAERDG, A. H.; UYTTENDAELE, M. Campylobacter contamination in broiler carcasses and correlation with slaughterhouses operational hygiene inspection. Food Microbiology, New York, v. 29, n. 1, p. 105-112, 2012.

MUSGROVE, M. T.; BERRANG, M. E.; BYRD, J. A.; STERN, N. J.; COX N. A. Detection of Campylobacter spp. in ceca and crops with and without enrichment. Poultry Science, Illinois, v. 80, n. 6, p. 825-828, 2001.

OYARZABAL, O. A.; MACKLIN, K. S.; BARBAREE, J. M.; MILLER, R. S. Evaluation of agar plates for direct enumeration of Campylobacter spp. from poultry carcass rinses. Applied Environmental Microbiology, Washington DC, v. 71, n. 6, p. 3351-3354, 2005.

PEARSON, A. D.; GREENWOOD, M.; HEALING, T. D.; ROLLINS, D.; SHAHAMAT, M.; DONALDSON, J.; COLWELL, R. R. Colonization of broiler chickens by waterborne campylobacter jejuni. Applied and Environmental Microbiology, Washington, DC, v. 59, n. 4, p. 987-996, 1993.
POTTURI-VENKATA, L. P.; BACKERT, S.; LASTOVICA, J. A.; VIEIRA, S. L.; NORTON, R. A.; MILLER, R. S.; PIERCE, S.; OYARZABAL, O. A. Evaluation of different plate media for direct cultivation of Campylobacter species from live broilers. Poultry Science, Illinois, v. 86, n. 7, p. 1304-1311, 2007.

SHREEVE, J. E.; TOSZEGHY, M.; PATTISON, M.; NEWELL, D. G. Sequential spread of Campylobacter infections in a multi pen broiler house. Avian Disease, Florida, v. 44, n. 4, p. 983-988, 2000.

THE WORLD ORGANISATION FOR ANIMAL HEALTH - OIE. Campylobacter jejuni and campylobacter coli. [S.1.]: Paris, 2008. Available at: $<$ http://www.oie.int/fileadmin/Home/eng/Health standards/tahm/2.09.03_CAMPYLO.pdf $>$. Accessed at: 03 jun. 2011.

UNITED STATES DEPARTMENT OF AGRICULTURE - USDA. Isolation, identification and enumeration of Campylobacter jejuni/coli/lari from poultry rinse and sponge samples. [S.1.]: Athens, 2011. Available at: $<$ http://www.fsis.usda.gov/PDF/MLG_41_01.pdf.2011>. Accessed at: 29 apr. 2011.

WORLD HEALTH ORGANIZATION - WHO. Campylobacter fact sheet $\mathrm{n}^{\circ} 255$. [S.1.]: Geneva, Switzerland, 2011. Available at: <http://www.who.int/ mediacentre/factsheets/fs255/en/index.html $>$. Accessed at: 03 nov. 2011. 
